Species Diversity. 1999, 4, 9-33

\title{
Rodinopora gen. nov. and the Taxonomy of Fungiform Cyclostome Bryozoans
}

\author{
Paul D. Taylor' and Andrei V. Grischenko \\ 'Department of Palaeonlology, The Natural History Museum, London SW7 5BD, UK \\ ${ }^{2}$ Department of Hydrobiology and Ichthyology, Faculty of Biology and Soil Sciences. \\ St Petersburg State University, 16 Liniya 29, St Petersburg, 199178. Russia
}

(Received 17 November 1997; Accepted 26 May 1998)

\begin{abstract}
A new cyclostome bryozoan, Rodinopora magnifica gen. et sp. nov., is described from the Sea of Okhotsk. It is compared with other genera of fossil and living bryozoans also having stalked, mushroom-shaped or fungiform colonies. This grow th-form is notable in being far commoner in cyclostomes than in any other orders of bryozoans. All existing fungiform cyclostome genera are reviewed and briefly redescribed. Seventeen genera are provisionally recognized. These are distributed among 10 nominal families as currently understood. Fungiform growth represents a strategy for elevating the feeding zooids above the surface of the substratum, potentially as a means of preventing overgrowth or of accessing regions of higher current flow in the boundary layer for feeding.

Key Words: Bryozoa, Cyclostomata, Sea of Okhotsk, taxonomy, fungiform grow th, functional morphology.
\end{abstract}

\section{Introduction}

Convergent evolution of homeomorphic colony-forms is a pervasive theme in bryozoan evolution (e.g. Taylor and McKinney 1996). Several of the commoner colony-forms have evolved independently on numerous occasions in clades belonging to widely differing taxonomic groups. Different bryozoan colony-forms represent alternative strategies for meeting the varying demands of a sessile, suspensionfeeding life on the sea-bed. Prominent among these requirements are acquisition of planktonic food, avoidance of predation, and success in obtaining living space.

A poorly-studied colony-form found in several bryozoan species can be termed 'fungiform' because of its mushroom-like shape. Fungiform colonies are typically small relative to other erect bryozoans. A narrow stalk is cemented to a hard substratum and supports the expanded head on which are located the feeding zooids. The discovery of a new fungiform bryozoan species in the Sea of Okhotsk, described here as Rodinopora magnifica gen. et sp. nov., has prompted a preliminary review of the taxonomy of living and fossil bryozoans having this distinctive growth-form.

The great majority of fungiform bryozoans belong to the Order Cyclostomata: 17 cyclostome genera are characterized by this growth-form. Although cheilostomes are of much greater diversity than cyclostomes at the present-day and in the fossil record since the mid-Cretaceous, they include very few species with fungiform colonies. Rare examples of fungiform cheilostome species are Myriapora fungiformis Vávra, 1983 from the German Oligocene (see Vávra 1983) and Semihaswellia umbrella Gordon and d'Hondt, 1997 from the Recent of New Caledonia (see Gordon 
and d'Hondt 1997). In addition, some cave-dwelling cheilostomes construct nodular to fungiform colonies through multilayered growth, as in Turbicellepora ampla (Kirkpatrick, 1888) illustrated by Scholz and Hillmer (1995: pl. 28, fig. 3), and Onychocella marioni Jullien, 1882 depicted by Harmelin (1985: fig. 3). No cheilostome genera consist exclusively of species having this colony-form. Furthermore, fungiform colonies are absent or very rare among the diverse orders of Palaeozoic bryozoans.

The aims of this paper are: (1) to describe a new fungiform cyclostome genus and species from the Sea of Okhotsk; and (2) to review the taxonomy and briefly consider the functional morphology of fungiform colonies.

Specimen repository abbreviations: NHM, The Natural History Museum, London; VH, Voigt Collection, Universität Hamburg (eventually destined for the Senckenburg Museum, Frankfurt).

\section{Systematics}

Rodinopora gen. nov.

Type species. Rodinopora magnifica sp. nov.

Diagnosis. Colony fungiform, simple; stalk formed of kenozooids, directed proximally near the base, distally near the top; head comprising low, radiating, multiserial fascicles of contiguous autozooidal apertures, with new fascicles arising by intercalation; interfascicular regions and centre of head occupied by kenozooids; autozooids free-walled, some with usually incomplete exterior-walled terminal diaphragms; kenozooids free-walled, closed by interior-walled diaphragms; gonozooid unknown.

Etymology. After the 'Rodino', the trawler that collected the bryozoan specimens.

Remarks. A full comparison between this new genus and established genera of cyclostomes with fungiform colonies is given below. Briefly, Rodinopora differs from Infundibulipora, probably the closest genus in morphology, in having the autozooids arranged in low fascicles that are not strongly inclined towards the edge of the colony (Figs 2-3), and in lacking the cystose kenozooids at the centre of the head found in the type species of Infundibulipora (Fig. 16).

The absence of brood chambers in the two known specimens of the monospecific Rodinopora is unfortunate as it conceals the familial affinities of the genus in a bryozoan order in which family-level classification is often problematical. Nevertheless, the distinctive skeletal characters in this new genus permit a detailed description to be made of skeletal morphology and warrant the establishment of the new genus. 
Rodinopora magnifica sp. nov.

(Figs 1-14)

Material. Holotype: NHM 1997.10.7.1, Sea of Okhotsk, Western Kamchatka Shelf, $57^{\circ} 36^{\prime} 2 \mathrm{~N}, 156^{\circ}$ 09'0 E, $75-88 \mathrm{~m}, \mathrm{~A}$. V. Grischenko coll., Sept. 1992. Paratype: NMH 1997.10.7.2, details as for holotype; a skeletally immature colony.

Etymology. From magnificus, Latin for splendid, referring to the spectacular, mushroom-shaped holotype colony.

Description. Colony fungiform, with a narrow stalk supporting a head or cap (Figs 1, 14). Stalk narrowest mid-way between attachment to substratum and boundary with head. Surface of stalk covered by kenozooids directed proximally towards substratum in lower part of stalk (Fig. 13) but distally towards head in upper part. Stalk kenozooids narrow, elongate, partitioned from adjacent kenozooids by thick, pustulose, vertical interzooidal walls, chambers oriented at an acute angle to surface of stalk, exposing long rear interzooidal walls with pores (Fig. 13). Interior of stalk formed of autozooids overgrown by surface kenozooids (Fig. 11). Head upper surface (Fig. 2) comprising three zones: a depressed inner zone (Fig. 4) occupied entirely by kenozooids; a broad middle zone (Fig. 3) consisting of slightly raised, radiating fascicles of autozooidal apertures, each fascicle two to five zooids wide, and interfascicular regions occupied by kenozooids continous with those of the head centre; and an outer zone (Fig. 9) formed of undifferentiated, newly-budded zooids increasing in size from the contact between stalk and head to the level at which autozooidal fascicles first appear. New fascicles intercalate between existing fascicles (Fig. 7). Early astogeny unknown.

Autozooids with contiguous apertures, large (average ca $0.24 \mathrm{~mm}$ ), typically hexagonal except for rounded apertures at edges of fascicles adjoining kenozooids. Apertural walls have dense pustules and are prolonged at triple junctions where three walls join (Fig. 8). Terminal diaphragms (Fig. 10) developed in many autozooids, including new buds (Fig. 9); located proximally of the apertural rim; most incompletely calcified with central hole and smooth outer surface (exterior wall), with teardrop-shaped pseudopores pointing centripetally in inferred direction of calcification. Sectioned autozooids long and tubular, their walls with abundant pores and sparse pustules proximal of terminal diaphragms but abundant pustules between diaphragms and apertures (Fig. 12).

Head kenozooids (Fig. 5) with polygonal apertures, variable in size, some almost equal in size to the autozooids but others smaller, including apparent new buds. Apertural walls very densely pustulose, wider and more rounded than autozooidal apertural walls. Apertures closed by interior-walled diaphragms (Fig. 6), positioned level with ends of interior walls or slightly below, pustulose and with pores containing minute centripetal spines partly occluding the pore. Kenozooids bordering fascicles are elongated parallel to raised fascicle.

Stalk kenozooids (Fig. 13) with very elongate, narrow apertures, intersecting stalk surface at a low angle, the thick, pustulose interzooidal walls between adjacent kenozooids forming an ornament of longitudinal ridges on the stalk surface. Rear walls of kenozooids pustulose and porous. Narrow distal fringe of basal lamina visible at the outer growing edge of stalk base and extending beyond first 

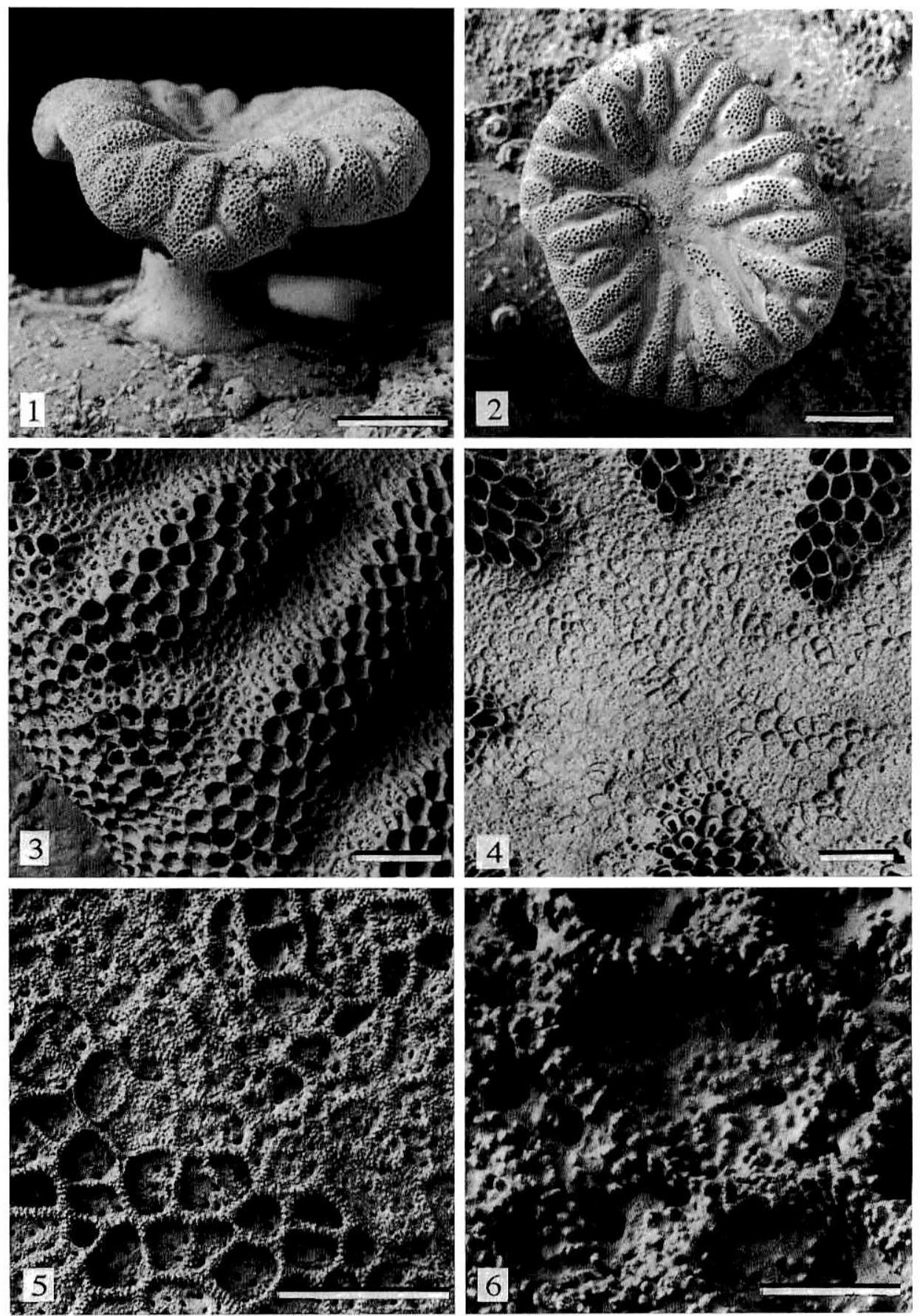

Figs 1-6. Rodinopora magnifica gen. et sp. nov., NHM 1997.10.7.1, bleached holotype specimen from Sea of Okhotsk: 1, lateral view of fungiform colony attached to surface of pebble; 2, upper surface of colony showing radial fascicles of autozooids surrounding central area lacking 
appearance of interzooidal walls.

Brood chambers not visible. Wall ultrastructure unknown.

Measurements. See Table 1.

Remarks. Three other fungiform cyclostomes from the northern Pacific are
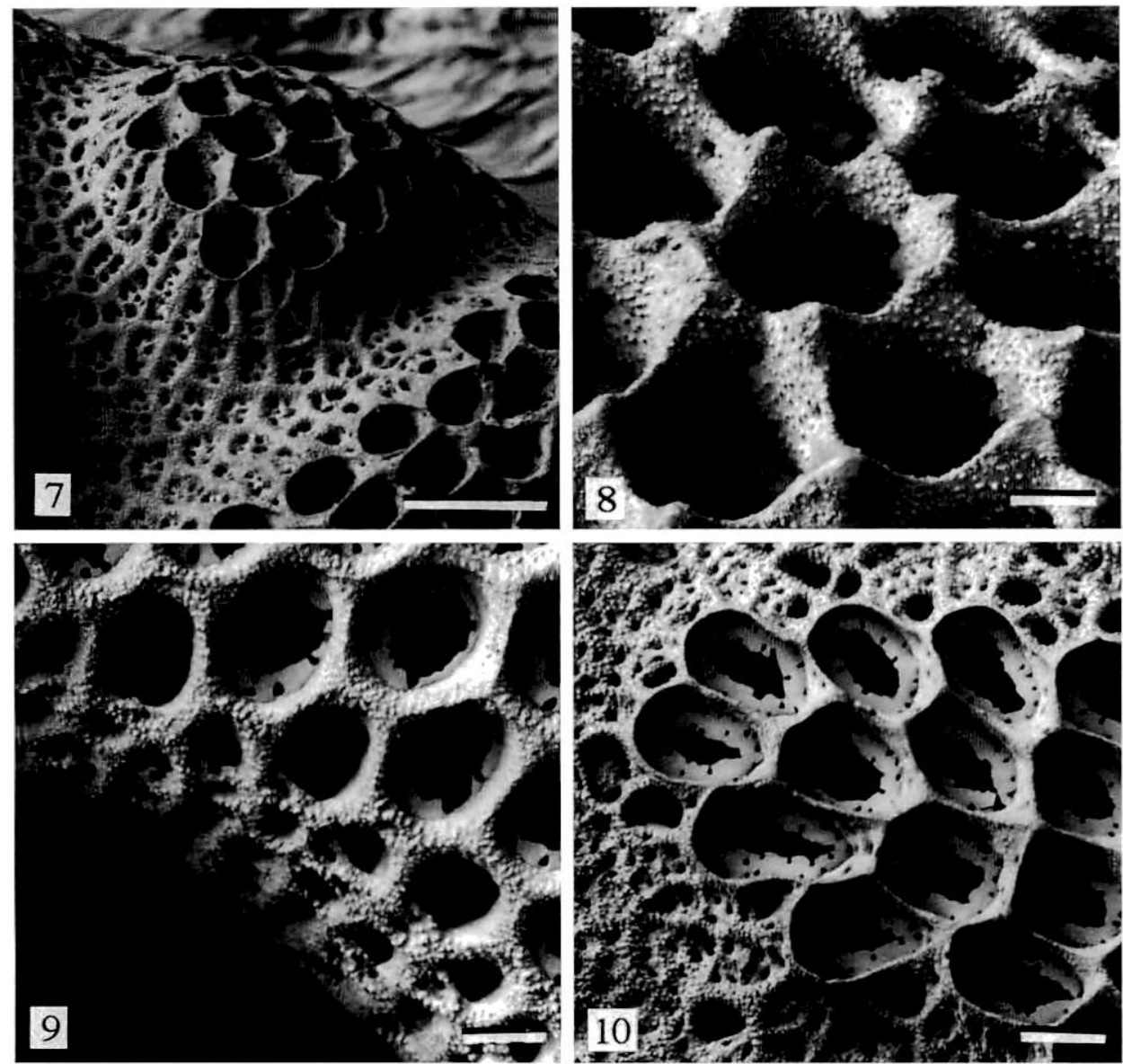

Figs 7-10. Rodinopora magnifica gen. et sp. nov., NHM 1997.10.7.1, bleached holotype specimen from Sea of Okhotsk: 7, new fascicle of autozooids at edge of colony; 8, detail of autozooidal apertures viewed obliquely to show prolongations at corners; 9, new buds at junction between stalk (lower left) and head (upper right); 10, partly-formed terminal diaphragms closing autozooidal apertures near inner edge of a fascicle. Scale bars: (7) $500 \mu \mathrm{m}$, (8) $100 \mu \mathrm{m}$, (9) 100 $\mu \mathrm{m}$, (10) $200 \mu \mathrm{m}$.

autozooids; 3, radial autozooidal fascicles separated by depressions occupied by kenozooids; 4 , inner zone of head with kenozooids; 5 , detail of kenozooids from inner zone of head; 6 , pustulose walls and interior-walled diaphragms with pores in kenozooids from inner zone of head. Scale bars: (1) $5 \mathrm{~mm}$, (2) $5 \mathrm{~mm}$, (3) $1 \mathrm{~mm}$, (4) $1 \mathrm{~mm}$, (5) $500 \mu \mathrm{m}$, (6) $100 \mu \mathrm{m}$. 

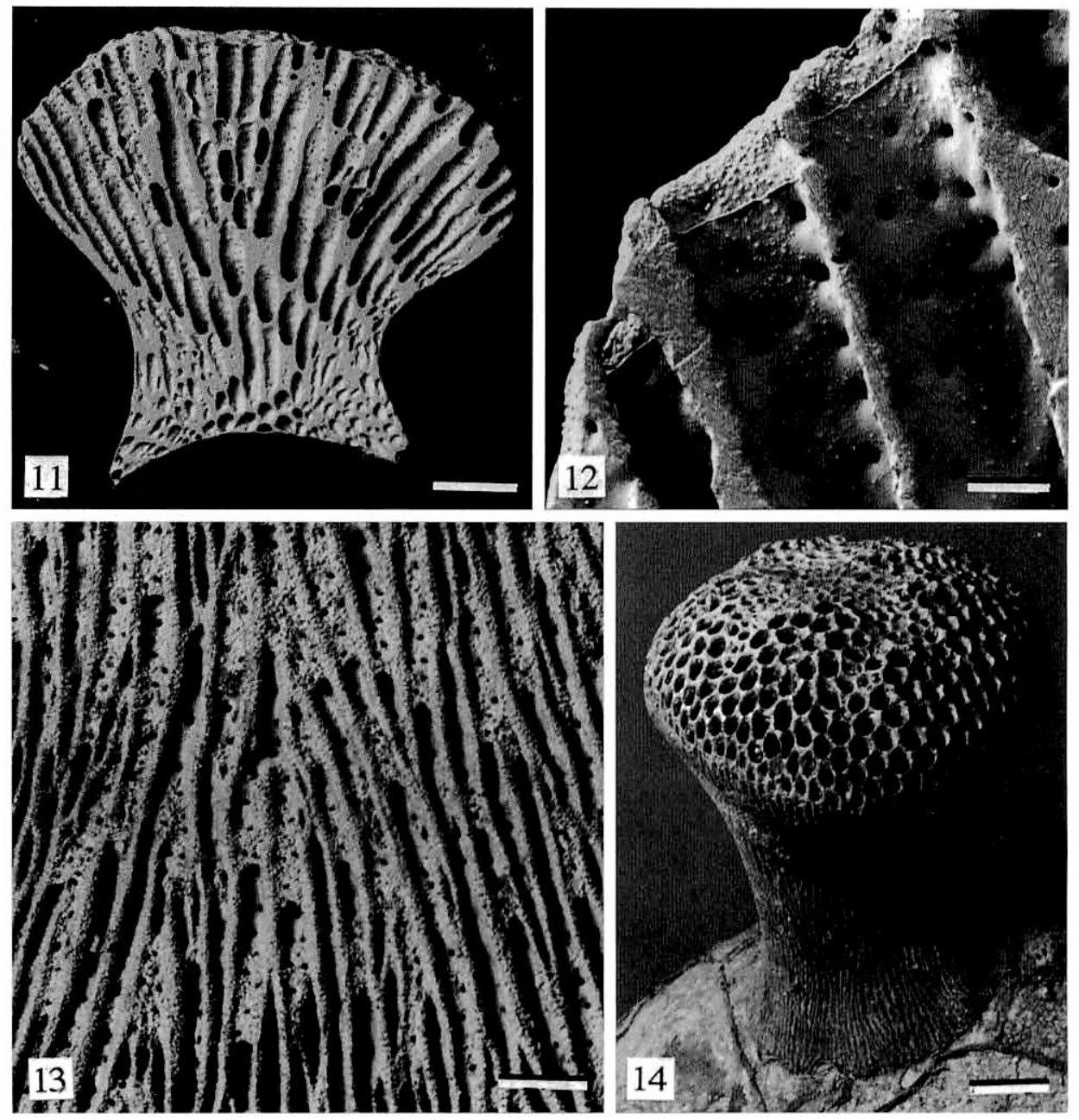

Figs 11-14. Rodinopora magnifica gen. et sp. nov. from Sea of Okhotsk: 11-12, 14, skeletally immature paratype specimen, NHM 1997.10.7.2: 11, vertical section showing tubular autozooids and kenozooids covering stalk on either side of concave colony base; 12, outer parts of autozooidal chambers, with porous walls and pustules concentrated beyond thin, apparently newly-formed, terminal diaphragms; 14 , oblique view of entire unbleached colony showing poor differentiation between autozooids and kenozooids on head; 13, proximally-directed kenozooids on stalk of bleached holotype specimen, 1997.10.7.1. Scale bars: (11) $1 \mathrm{~mm}$, (12) $100 \mu \mathrm{m}$, (13) $200 \mu \mathrm{m}$, (14) $1 \mathrm{~mm}$.

comparable with R. magnifica: Infundibulipora lucernaria (Sars, 1851), Discocytis canadensis O'Donoghue \& O'Donoghue, 1926, and Discocytis californica Osburn, 1953. Rodinopora magnifica differs from all of these species in having autozooidal fascicles of low profile that do not project beyond the outer edge of the head. In addition, the cyst-like kenozooids in the centre of the head of I. lucernaria (Fig. 16) are very different from the equivalent kenozooids in R. magnifica (Fig. 5). 
Table 1. Dimensions of Rodinopora magnifica gen. et sp. nov.

\begin{tabular}{lcc}
\hline & Holotype & Paratype \\
\hline Colony height & $11 \mathrm{~mm}$ & $6 \mathrm{~mm}$ \\
Head width (maximum) & $20 \mathrm{~mm}$ & $6 \mathrm{~mm}$ \\
Stalk width (minimum) & $5.8 \mathrm{~mm}$ & $2.7 \mathrm{~mm}$ \\
$\begin{array}{l}\text { Width of inner zone of head with } \\
\text { kenozooids }\end{array}$ & $2.5 \times 4.1 \mathrm{~mm}$ & - \\
$\begin{array}{l}\text { Fascicle width } \\
\text { Spacing between fascicles }\end{array}$ & $0.7-1.6 \mathrm{~mm}$ & - \\
$\begin{array}{l}\text { Autozooid aperture diameter (trans- } \\
\text { verse) }\end{array}$ & $0.21-0.27 \mathrm{~mm}$ & - \\
$\begin{array}{l}\text { Head kenozooid aperture diameter } \\
\begin{array}{l}\text { Stalk kenozooid aperture diameter } \\
\text { (width) }\end{array}\end{array}$ & $0.08-0.22 \mathrm{~mm}$ & - \\
\hline
\end{tabular}

Distribution and ecology. This species is known only from the Sea of Okhotsk, Western Kamchatka Shelf, at a depth of $75-88 \mathrm{~m}$. Grischenko et al. (in press) have summarized our state of knowledge of the bryozoan faund of the Sea of Okhotsk. Most of this relatively enclosed basin is shallower than $1000 \mathrm{~m}$. The bryozoans are predominantly components of upper-shelf benthic communities. Their diversity was estimated by Kluge (1953) to be approximately 140 species and by Androsova (1962) to exceed 200 species. Omitting the Kuril Islands, the following cyclostome species have been recorded from the Sea of Okhotsk: Borgella tumulosa Kluge, 1955 , Crisia eburnea (Linnaeus, 1758), C. denticulata (Lamarck, 1816), Diplosolen intricarius (Smitt, 1872), D. obelia var. arctica (Waters, 1904), Fasciculiporoides americana (d'Orbigny, 1853), Heteropora pelliculata Waters, 1879, 'Lichenopora' neviani Borg, 1944, 'L': radiata (Audouin, 1826), Oncousoecia canadensis Osburn, 1933, O. diastoporoides (Norman, 1869), and Tubulipora ventricosa Busk, 1855.

In the area of occurrence of $R$. magnifica, the average annual temperature range is $-2.5^{\circ} \mathrm{C}$ in winter to $0.4^{\circ} \mathrm{C}$ in summer, and salinity varies from $33.0-33.2 \mathrm{ppt}$ at $50 \mathrm{~m}$ to $33.25 \mathrm{ppt}$ at $200 \mathrm{~m}$. Current velocities on the sea-bed are generally moderate to strong. A rich encrusting benthos occupies up to $11 \%$ of the sea-bed in the sampled habitat (Savilov 1961). Bryozoan biomass here is $8.2 \%$ of total benthic biomass (Izyumova 1977). Co-occuring invertebrates include sponges, asteroids, serpulid polychaetes, hydroids, brachiopods, and barnacles, as well as numerous other bryozoan species.

Both known colonies of $R$. magnifica were cemented to pebbles colonized by various bryozoans and encrusting animals. Although the large holotype colony gives every indication of being skeletally mature, no brood chambers are visible at the surface. It is possible that brood chambers are present but completely overgrown. However, testing this idea would require sacrificing this unique specimen. By 
comparison with the holotype the much smaller paratype colony is skeletally immature, showing poor development of fascicles and a narrow head which is little wider than the stalk (Fig. 14). Therefore, it was not surprising that a vertical section of the specimen (Fig. 11) failed to reveal the existence of internal brood chambers.

The widespread development of partial terminal diaphragms in the holotype colony, even in small, newly-budded autozooids (Fig. 9), suggests that the colony was commencing a period of dormancy when collected in September, 1992. Similar but less well-developed diaphragms are also present in the paratype collected at the same time. The vertical section of this colony reveals the presence of at least one earlier-formed level with partial diaphragms and the associated proximal to distal change from sparse to abundant wall pustules on each side of the diaphragm. This evidence suggests that colonies of $R$. magnifica grow according to the following sequence: (1) summertime active feeding and growth including lengthening of the autozooidal tubes, expansion of the head, and thickening of the stalk by kenozooidal overgrowths; (2) late summer slowing of skeletal growth (indicated by the progressive increase in density of pustules) and centripetal secretion of terminal diaphragms to seal the autozooidal apertures; (3) overwintering in a dormant state; and (4) springtime resorption of terminal diaphragms and resumption of feeding and growth. A relatively slow rate of colony growth and a perennial life history are indicated.

\section{Fungiform Cyclostome Bryozoan Genera}

Fungiform colonies (Figs 1, 14, 18, 20) constitute a reasonably distinctive growth-form in bryozoans characterized by a narrow stalk, invariably devoid of autozooidal apertures, supporting an expanded head on which the autozooids open. The growth-form is almost entirely restricted to the Order Cyclostomata. Eighteen recognizable cyclostome genera can be defined by possession of a fungiform colony. These range in age from Middle Jurassic to Recent, and at the present-day they occur in geographical regions from the Arctic to Antarctic. Fungiform colonies were particularly common in the Late Cretaceous, at a time when the taxonomic diversity and morphological disparity of cyclostomes apparently peaked.

Principal differences between genera (Table 2) relate to the surface character of the stalk (calcified exterior wall (e.g. Fig. 21) or kenozooids (c.g. Fig. 13)), the location of the gonozooid (upperside, edge, or underside of head) and its frontal wall structure (free- or fixed-walled, i.e. constructed of interior or exterior wall respectively), the distribution of autozooidal apertures (in fascicles or otherwise) and their wall structure (free- or fixed-walled), the presence or absence of kenozooids on the surface of the head, and the extent to which the fascicles or branches are prolonged beyond the outer margin of the head. There are also variations in the smoothness or abruptness of the transition between stalk and head, and in the relief of the upper surface of the head, which can be concave, flat, or convex.

The brief descriptions of genera arranged alphabetically below are very provisional; they are based mainly on the respective type species and focus only on the characters that are explicit in the literature. This invariably means that internal characters and wall ultrastructure, both of considerable potential taxonomic utility, are omitted. A tentative key for generic identification is given in the Appendix. 
Table 2. Principal character states in fungiform cyclostomes.

\begin{tabular}{|c|c|c|c|c|c|c|}
\hline Genus & $\begin{array}{l}\text { Brood } \\
\text { chamber } \\
\text { location }\end{array}$ & $\begin{array}{l}\text { Brood } \\
\text { chamber } \\
\text { structure }\end{array}$ & $\begin{array}{l}\text { Stalk } \\
\text { surface }\end{array}$ & $\begin{array}{l}\text { Autozooid } \\
\text { structure }\end{array}$ & $\begin{array}{l}\text { Auto\%ooid } \\
\text { distribution }\end{array}$ & $\begin{array}{l}\text { Differentiated } \\
\text { head } \\
\text { kenozooids }\end{array}$ \\
\hline Amphimarssoniella & $\begin{array}{l}\text { peripheral } \\
\text { edge }\end{array}$ & $\begin{array}{l}\text { fixed- } \\
\text { walled }\end{array}$ & kenozooids & free-walled & $\begin{array}{l}\text { entire upper } \\
\text { head surface }\end{array}$ & no \\
\hline Apsendesia & $\begin{array}{l}\text { upper side } \\
\text { peripheral }\end{array}$ & $\begin{array}{l}\text { fixed- } \\
\text { walled }\end{array}$ & $\begin{array}{l}\text { exterior } \\
\text { wall }\end{array}$ & $\begin{array}{l}\text { fixed- } \\
\text { walled }\end{array}$ & $\begin{array}{l}\text { radial } \\
\text { fascicles }\end{array}$ & no \\
\hline Bicavea & $?$ & $?$ & kenozooids & free-walled & $\begin{array}{l}\text { radial } \\
\text { fascicles }\end{array}$ & yes \\
\hline Discocytis & $\begin{array}{l}\text { under side } \\
\text { peripheral }\end{array}$ & $\begin{array}{l}\text { fixed- } \\
\text { walled }\end{array}$ & kenozooids & $\begin{array}{l}\text { fixed- } \\
\text { walled }\end{array}$ & $\begin{array}{l}\text { radial } \\
\text { fascicles }\end{array}$ & no \\
\hline Discofascigera & $?$ & ? & $\begin{array}{l}\text { exterior } \\
\text { wall }\end{array}$ & free-walled & $\begin{array}{l}\text { interspersed } \\
\text { with } \\
\text { kenozooids }\end{array}$ & yes \\
\hline Discotruncalulipora & peripheral & $\begin{array}{l}\text { fixed- } \\
\text { walled }\end{array}$ & $\begin{array}{l}\text { exterior } \\
\text { wall }\end{array}$ & $\begin{array}{l}\text { fixed- } \\
\text { walled }\end{array}$ & $\begin{array}{l}\text { radial } \\
\text { fascicles }\end{array}$ & no \\
\hline Fasciculiporina & $\begin{array}{l}\text { upper side } \\
\text { central }\end{array}$ & $\begin{array}{l}\text { fixed- } \\
\text { walled }\end{array}$ & $\begin{array}{l}\text { exterior } \\
\text { wall }\end{array}$ & free-walled & $\begin{array}{l}\text { entire upper } \\
\text { head surface }\end{array}$ & no \\
\hline Flosculipora & $\begin{array}{l}\text { upper side } \\
\text { central }\end{array}$ & $\begin{array}{l}\text { fixed- } \\
\text { walled }\end{array}$ & kenozooids & free-walled & $\begin{array}{l}\text { interspersed } \\
\text { with } \\
\text { kenozooids }\end{array}$ & yes \\
\hline Fungella & $\begin{array}{l}\text { upper side } \\
\text { central }\end{array}$ & free-walled & kenozooids & free-walled & $\begin{array}{l}\text { entire upper } \\
\text { head surface }\end{array}$ & no \\
\hline Infundibulipora & $\begin{array}{l}\text { upper side } \\
\text { peripheral }\end{array}$ & $\begin{array}{l}\text { fixed- } \\
\text { walled }\end{array}$ & kenozooids & free-walled & $\begin{array}{l}\text { radial } \\
\text { fascicles }\end{array}$ & yes \\
\hline Marssoniella & $\begin{array}{l}\text { upper side } \\
\text { central }\end{array}$ & $\begin{array}{l}\text { fixed- } \\
\text { walled }\end{array}$ & kenozooids & free-walled & $\begin{array}{l}\text { entire upper } \\
\text { head surface }\end{array}$ & no \\
\hline Neofungella & $\begin{array}{l}\text { upper side } \\
\text { central }\end{array}$ & $\begin{array}{l}\text { ?fixed- } \\
\text { walled } \\
\text { (overgrown) }\end{array}$ & kenozooids & free-walled & $\begin{array}{l}\text { interspersed } \\
\text { with } \\
\text { kenozooids }\end{array}$ & yes \\
\hline Rodinopora & ? & ? & kenozooids & free-walled & $\begin{array}{l}\text { radial } \\
\text { fascicles }\end{array}$ & yes \\
\hline Penciletta & $\begin{array}{l}\text { upper side } \\
\text { central }\end{array}$ & $\begin{array}{l}\text { fixed- } \\
\text { walled }\end{array}$ & $\begin{array}{l}\text { exterior } \\
\text { wall }\end{array}$ & $\begin{array}{l}\text { fixed- } \\
\text { walled }\end{array}$ & $\begin{array}{l}\text { entire upper } \\
\text { head surface }\end{array}$ & no \\
\hline Supercytis & $\begin{array}{l}\text { upper side } \\
\text { central }\end{array}$ & $\begin{array}{l}\text { fixed- } \\
\text { walled }\end{array}$ & $\begin{array}{l}\text { exterior } \\
\text { wall }\end{array}$ & free-walled & $\begin{array}{l}\text { radial } \\
\text { fascicles }\end{array}$ & no \\
\hline Telopora & $\begin{array}{l}\text { upper side } \\
\text { central }\end{array}$ & $\begin{array}{l}\text { fixed- } \\
\text { walled }\end{array}$ & $\begin{array}{l}\text { exterior } \\
\text { wall }\end{array}$ & $\begin{array}{l}\text { fixed-or } \\
\text { free-walled }\end{array}$ & $\begin{array}{l}\text { radial } \\
\text { fascicles }\end{array}$ & yes \\
\hline Trochiliopora & $\begin{array}{l}\text { upper side } \\
\text { central }\end{array}$ & $\begin{array}{l}\text { free- } \\
\text { walled }\end{array}$ & kenozooids & free-walled & $\begin{array}{l}\text { radial } \\
\text { connate } \\
\text { uniserial } \\
\text { rows }\end{array}$ & yes \\
\hline
\end{tabular}

* based on Trochiliopora? insignis (Manzoni, 1878) as redescribed by Schattleitner (1991:396, pl. 2, figs 2-3) 
Amphimarssoniella Voigt, 1974

Type species. Amphimarssoniella klaumanni Voigt, 1974.

Description. Colony fungiform, simple; stalk formed of kenozooids arranged in longitudinal series; head depressed, comprising free-walled autozooids, some with sunken frontal interior walls and distal apertures (central in the axial zooid), occasionally occluded by exterior-walled terminal diaphragms, autozooids decreasing in sizc from head centre towards edge; gonozooid located at periphery of head, narrow, transversely elongate, with exterior frontal wall.

Remarks. This monospecific genus is distinguished by the extremely broad brood chamber located at the periphery of the head (Fig. 18) and also by the development of sunken frontal walls in the autozooids on the head surface. Because of their lack of pseudopores and smooth transition into the supporting vertical walls, these autozooidal frontal walls are inferred to be calcified interior walls. They contrast in appearance with the pseudoporous, exterior-walled terminal diaphragms which occasionally close autozooidal apertures. In most specimes the roof of the gonozooid is not preserved, leaving a narrow slit around the circumference of the head which is the chamber of the gonozooid (Fig. 18).

Voigt (1974) assigned his genus to the Family Corymboporidae, noting its similarities to Marssoniella.

Distribution. Cretaceous (Cenomanian), Westfalia, Germany.

Apsendesia Lamouroux, 1821

Type species. Apsendesia cristala Lamouroux, 1821.

Description. Colony fungiform and simple, or compound, complex and nonfungiform; stalk formed of exterior wall, often with hollow struts for secondary attachment; head comprising radial fascicles of autozooids, fascicles extending significantly beyond edge of head as flat, bifurcating branches, bounded and separated by exterior wall, without intervening kenozooids; autozooids opening around edge of head; gonozooid located at periphery of head between fascicles, elongate, with exterior frontal walls and a tiny ooeciopore.

Remarks. The type species of this genus from the Jurassic of Europe was redescribed by Walter (1970) and more recently by Ilara and Taylor (1996). Following the removal of the Miocene species $A$. fasciculata Reuss, 1848 to Bobiesipora by Vávra (1978), only one other formally-described species is currently recognized, the rare $A$. neocomiensis from the Cretaceous (Valanginian) of France (see Walter 1986). In addition, the A. cristata of Walter (1967), which is slightly older (Bajocian) than the type occurrence of $A$. cristata (Bathonian), may represent a third species, but the rare available material is apparently immature (Hara and Taylor 1996).

Colonies of Apsendesia may be simple and fungiform with a narrow stalk and broad, flat head (the form described by Lamouroux (1821) as Pelagia clypeata), or compound with clusters of subcolonies and lacking an obvious fungiform morphology. In the type species, the development of kenozooidal struts on the underside of the head and the elongate gonozooids developed in the clefts between fascicles are particularly characteristic features. 

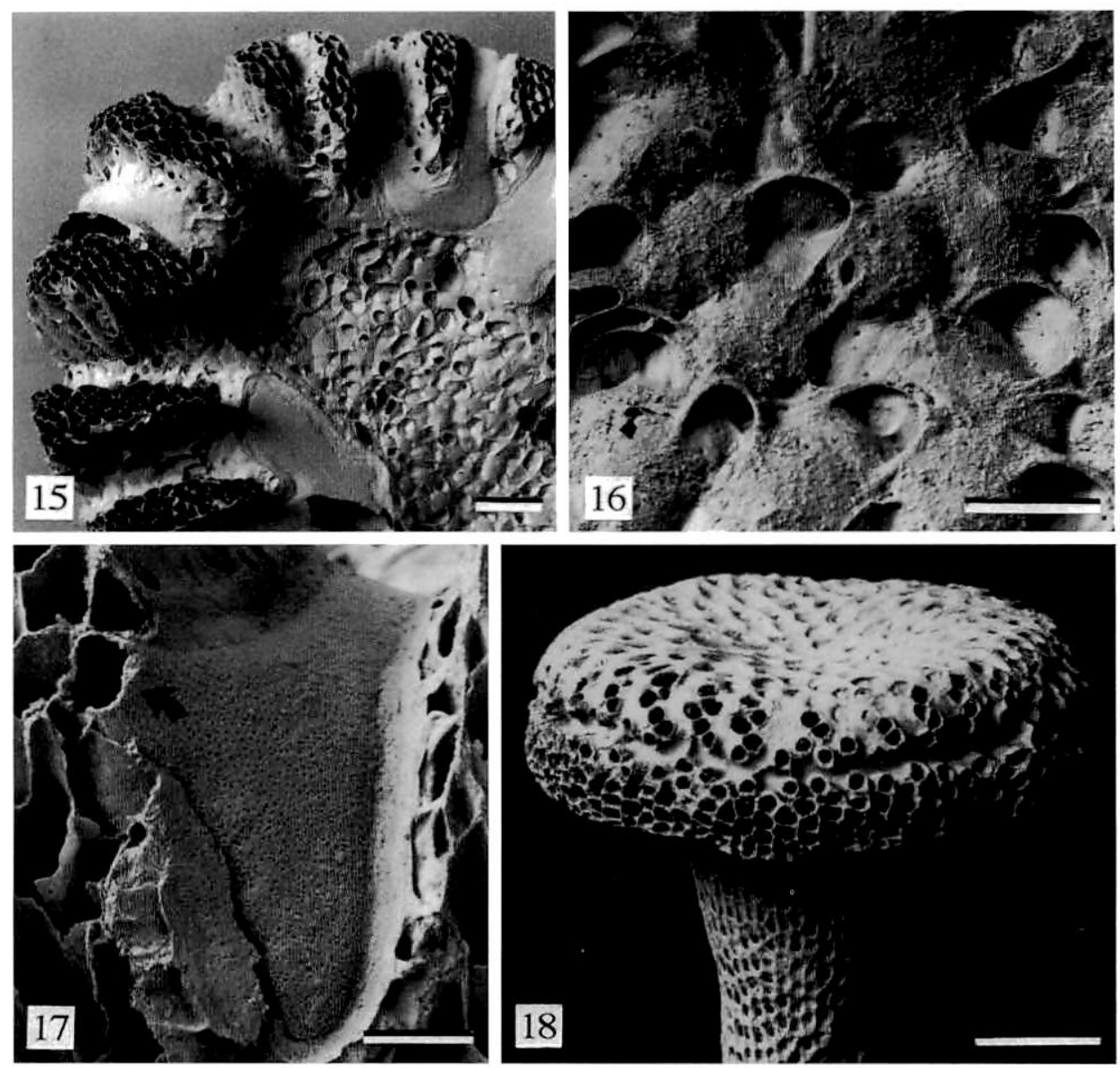

Figs 15-17. Infundibulipora lucernaria (Sars, 1851), Norway, NHM 11.10.1.228; 15, part of upper head surface with cyst-like kenozooids at centre, raised autozooidal fascicles projecting beyond edge of head, and smooth frontal walls of gonozooids; 16, detail of cyst-like kenozooids; 17 , gonozooid with damaged ooeciopore (arrowed). Fig. 18, Amphimarssoniella klaumanni Voigt, 1974, Cretaceous, Lower Cenomanian, Mülheim, Germany, NHM D59208, profile of colony showing stalk and edge of head with fissure-like, roof-less gonozooid. Scale bars: (15) $1 \mathrm{~mm}$, (16) $200 \mu \mathrm{m},(17) 200 \mu \mathrm{m},(18) 1 \mathrm{~mm}$.

Apsendesia has been referred either to the Fasciculiporidae or the Theonoidae, both families of tubuliporines with autozooids in fascicles. Europe.

Distribution. Jurassic (?Bajocian, Bathonian) - Cretaceous (Hauterivian),

\section{Bicavea d'Orbigny, 1853}

Type species. Fasciculipora urnula d'Orbigny, 1850.

Description. Colony fungiform, simple or compound with stacked subcolonies 

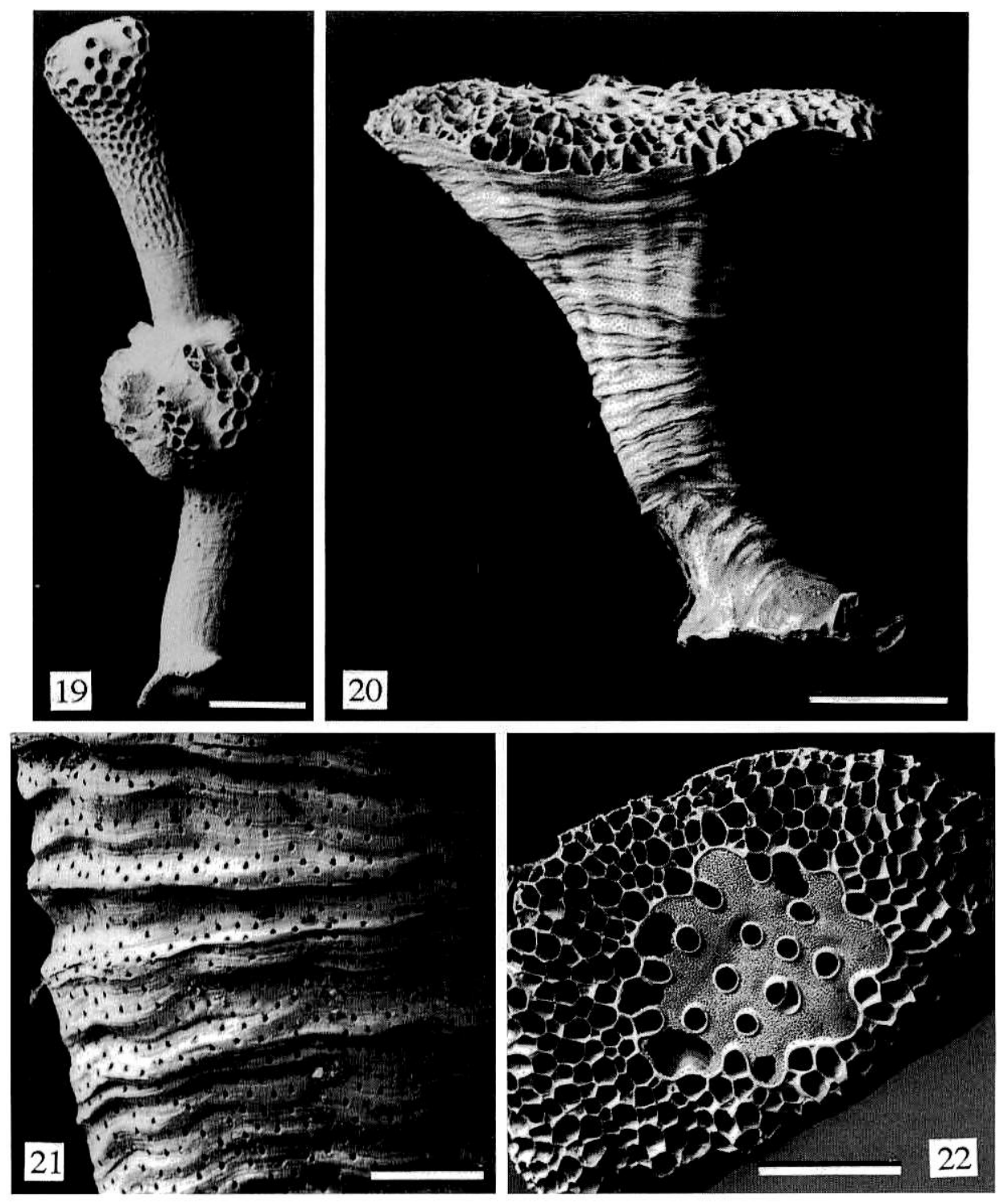

Fig. 19. Bicavea pergensi Gregory, 1907, Paleocene, Danian, Faxe, Denmark, VH 13955, compound fungiform colony with daughter subcolony growing from upper surface of parent subcolony. Figs 20-22, Telopora watersi (Harmer, 1915), Siboga Station 213, Saleyer, Malay Archipelago, NHM 16.8.23.104: 20, colony profile; 21, pseudoporous, exterior-walled calcification forming stalk; 22, upper surface of head showing gonozooid penetrated by autozooidal apertures. Scale bars: (19) $1 \mathrm{~mm}$, (20) $1 \mathrm{~mm}$, (21) $200 \mu \mathrm{m}$, (22) $1 \mathrm{~mm}$. 
(Fig. 19); stalk formed of kenozooids; head vase-shaped, the upper surface depressed, comprising radial fascicles of autozooids, fascicles extending beyond edge of head, bounded by interior wall and separated by kenozooids continuous with those of stalk; centre of head comprising large, open, polygonal ?kenozooids; autozooids opening around edge of head; gonozooid unknown.

Remarks. The poorly-known type species comes from the Upper Cretaceous of France and was initially described by d'Orbigny (1850) and first figured by the same author (1853: pl.776, figs 1-2), who depicted an almost conical colony with the stalk grading imperceptibly into the head, the surfaces of both being covered by kenozooids. Radial fascicles of autozooids protrude from the upper surface of the head of B. urnula, oriented obliquely upwards and outwards. Radiopora urnula (d'Orbigny, 1850) sensu Pergens and Meunier (1887) from the Paleocene (Danian) of Faxe appears to lack kenozooids on the head and has strong radial fascicles of autozooids. It is unlikely to be conspecific with d'Orbigny's species or genus.

Unfortunately, the brood chamber is unknown in both the type species of Bicavea and in the common British Chalk species, B. rotaformis Gregory, 1907 (see Gregory 1907, 1909b; Taylor 1987) which, in comparison with B. urmula, has a clearer differentiation between stalk and head, with a depression between the two, deeper fascicles with autozooidal apertures opening more laterally, and of ten develops compound colonies. (In B. urnula sensu Pergens and Meunier (1887), the brood chamber is positioned on the upper surface of the head and has a roof of exterior wall).

Bassler (1953) assigned Bicavea to the Cytididae, as did Brood (1972: 339), who thought it possible that Bicavea was a junior subjective synonym of Osculipora d'Orbigny, 1849.

Distribution. Cretacceus (Turonian)- Paleocene (Danian), Europe. Note that the Paleocene species, Bicavea pergensi Gregory, 1907 (Fig. 19) was regarded by Brood (1972: 327) as a junior synonym of Theonoa disticha (v. Hagenow, 1851).

\section{Discocytis d'Orbigny, 1854}

Type species. Pelagia eudesii Michelin, 1844.

Description. Colony fungiform, simple; stalk covered by kenozooids; head comprising bifurcating radial fascicles of autozooids, fascicles not extending significantly beyond edge of head, bounded and separated by exterior wall, without kenozooids; autozooids opening on upper surface and around edge of head; gonozooids located on underside of head, subcircular, with exterior frontal walls.

Remarks. The type species of d'Orbigny's (1854) genus Discocytis, D. eudesii from the Cenomanian of France, originally described by Michelin (1844), was refigured by Canu and Bassler (1922: 71, pl. 28, figs 10-15; fig. 15 in text) and by Voigt (1981: fig. 2c-d). Two other Cretaceous species, D. infundibuliformis (Ilennig, 1894) and $D$. bettenstaedi Voigt, 1951, have very concave upper head surfaces, seemingly made from exterior wall calcification (Voigt 1951: pl. 3, figs 6-9; Brood 1972: pl. 34, figs 6-7), and lack the radial fascicles seen in the type species. The brood chamber of D. eccentrica Ulrich \& Bassler, 1907, from the Paleocene Vincentown Limesand, was figured by Schäfer (1991: pl. 38, figs 1-2). In all fossil species for which it is known, the gonozooid is roofed by exterior wall (i.e. fixed-walled) and is 
located on the upper surface of the head.

Two living species from the Pacific Coast of North America have been assigned to Discocytis: D. canadensis O'Donoghue and O'Donoghue, 1926 and D. californica Osburn, 1953. Schäfer (1991: pl. 38, figs 3-4) depicted in putative D. canadensis a free-walled brood chamber which could be located on either the underside or upper surface of the head (see also Ross 1970). To judge from Osburn's (1953) figure, the bulbous brood chamber of $D$. californica is fixed-walled and is located beneath the head. Furthermore, the stalk of $D$. californica, in contrast to the type species, may be of exterior wall: Osburn (1953, p. 690) stated 'The base and stem show no tubules and appear as if covered by a thin pellicle'. Given the differences in brood chamber location and structure, it is doubtful whether either of these Recent species really belongs to Discocytis.

Both Bassler (1953) and Brood (1972) referred Discocytis to the Cytididae.

Distribution. Cretaceous (Cenomanian) - Paleocene (Thanetian), ?Recent, Europe and North America.

\section{Discofascigera d'Orbigny, 1853}

Type species. Discofascigera ligeriensis d'Orbigny, 1853.

Description. Colony fungiform, simple; stalk comprising exterior wall; head having free-walled autozooids opening across entire upper surface, interspersed with smaller, free-walled kenozooids; gonozooid unknown (?).

Remarks. According to Canu and Bassler (1920: 808), the gonozooid is unknown in the type or other species (see Gregory 1909b: 30) referred to Discofascigera. Voigt (1973: 131) mentioned the occurrence of a gonozooid in D. rosula (v. Hagenow, 1839), but this appears never to have been described or figured.

Bassler (1953) placed the genus in the Frondiporidae. However, there is a clear need for more work to establish the distinguishing characteristics, validity, and classification of Discofascigera.

Distribution. Cretaceous (Albian) - Miocene, Europe, Australia.

Discotruncatulipora Flor, 1975

Type species. Discotruncatulipora corbis Flor, 1975.

Description. Colony fungiform or subfungiform, simple, fan-shaped in plan view; stalk formed of exterior wall; head comprising radial fascicles of autozooids, fascicles extending well beyond edge of head as flat, bifurcating branches, bounded and separated by exterior wall, without kenozooids; autozooids opening around edge of head; gonozooids visible on underside between fascicles at edge of head, ovoidal, with exterior frontal walls, ooeciopore opening on frontal surface.

Remarks. This monospecific Cretaceous genus resembles Apsendesia but has colonies that are fan-shaped when viewed from above, and broader gonozooids more clearly visible from the underside.

Flor (1975) placed Discotruncatulipora in the Cytididae.

Distribution. Cretaceous (Cenomanian - Turonian), Europe. 
Fasciculiporina Voigt, 1973

Type species. Fasciculiporina pockrandti Voigt, 1973.

Description. Colony fungiform, simple; stalk formed of exterior wall; head depressed centrally, comprising free-walled autozooids, larger near centre without differentiated kenozooids; gonozooids located centrally on upper surface of head, roofed by cxterior frontal wall, (?) overgrown by later zooids.

Remarks. The large zooids at the centre of the head are a very conspicuous feature of the Santonian type species. A second species subsequently placed in Fasciculiporina by Voigt (1987) is F. plicata (v. Hagenow, 1851) from the Maastrichtian and Danian. Here the head lacks large zooids but shows interspersed autozooids and kenozooids. This species may not be congeneric with $F$. pockrandti. Voigt (1987: 26) did not assign Fasciculiporina to a family, but his comparison of the genus with Fasciculipora suggests a provisional assignment to the Frondiporidae.

Distribution. Cretaceous (Santonian) - ?Paleocene (Danian), Europe.

Flosculipora MacGillivray, 1886

Type species. Flosculipora pygmaea MacGillivray, 1886.

Description. Colony fungiform, simple, very small; stalk formed of kenozooids; head comprising free-walled autozooids interspersed with free-walled kenozooids, the former not in fascicles but developing a radial arrangement near periphery of head; gonozooid located on upper surface of head with roof of apparent exterior wall, overgrown by later zooids.

Remarks. MacGillivray (1886) assigned this monospecific genus to the rectangulate family Discoporellidae, equivalent to the Disporellidae Borg, 1944 of modern usage (see Borg 1944). He did not describe the brood chamber. However, a topotype specimen in the NHM (1897.5.1.1178) has a partly overgrown gonozooid with a roof seemingly of exterior wall, implying a cerioporine grade of organization and necessitating transfer of the genus to a different, as yet unknown family.

Bassler (1953) incorrectly gave the date of the genus as 1887.

Distribution. Recent, Victoria, Australia.

Fungella v. Hagenow, 1851

Ty pe species. Fungella dujardini v. Hagenow, 1851.

Description. Colony fungiform, simple; stalk formed of kenozooids; head convex, surface covered by polygonal apertures of free-walled autozooids (and (?) kenozooids); gonozooid located on head, interior-walled, overgrown by later zooids.

Remarks. The Upper Cretaceous type species, originally described by $v$. Hagenow (1851), was revised by Voigt (1951) and Brood (1972), and its free-walled brood chamber figured by Schäfer (1991: text-fig. 49, pl. 31, figs 1-4). Fungella dalli Kluge, 1955 (see Kluge 1975: 212, fig. 92) from the Arctic Ocean was based on one (or a few) small colonies, apparently infertile. The affinities of this modern species are unclear, although Buge and Tillier (1977) placed it in Neofungella Borg, 1933.

Both Brood (1972) and Voigt (1974) classified Fungella in the Corymboporidae, 
while Kluge (1955) established the family Fungellidae for its reception.

Distribution. Cretaceous (Campanian-Maastrichtian) - ?Recent, Europe.

\section{Infundibulipora Brood, 1972}

Type species. Tubulipora lucernaria Sars, 1851.

Description. Colony fungiform, simple; stalk surface formed of kenozooids; head with radial fascicles of free-walled autozooids (Fig. 15), new fascicles intercalating between old; cystose, free-walled kenozooids at head centre (Fig. 16) and between fascicles; gonozooids located between fascicles on upper surface near edge of head, roofed with exterior wall; ooeciopore adnate to a fascicle (Fig. 17).

Remarks. Schäfer (1991: pl. 47, figs 1-2) depicted the brood chamber in Sars' (1851) type species of Infundibulipora, which she referred to as 'Defranceia lucernaria'. Another species, Defrancia prolifera Kluge, 1946, was later referred to as D. lucernaria var. prolifera by Kluge (1975). However, it does not closely resemble Sars' species and is unlikely to be closely related.

Two fossil species have been assigned to Infundibulipora: I. huckriedei Voigt, 1977 from the Upper Cretaceous (Campanian or Maastrichtian) of Iran and Sweden, and I. hesslandi Brood, 1972 from the Paleocene (Danian) of Denmark and Sweden. Brood chamber roof structure is uncertain in both of these species and therefore their true generic identity is difficult to ascertain. It is possible that they may be more appropriately placed in either Bicavea d'Orbigny, 1853 or Trochiliopora Gregory, 1909a.

According to Brood (1972: 322), Infundibulipora differs from Marssoniella in having autozooecia grouped in fascicles that protrude above the colony surface in contrast to the non-fasciculate, flush autozooids of Marssoniella.

Infundibulipora was included in the family Corymboporidae by Brood (1972), whereas Voigt (1977) regarded it as a member of the rectangulate family Lichenoporidae on account of the morphology of the 'zoarial brood chamber'. However, the organizational grade of the type species I. lucernaria is cerioporine rather than rectangulate (i.e. the brood chamber roof consists of exterior rather than interior wall). The most appropriate familial assignment for Infundibulipora remains unclear.

Distribution. ?Cretaceous (Campanian) - Recent, Europe and $\Lambda$ sia.

\section{Marssoniella Levinsen, 1925}

Type species. Marssoniella reticulala Levinsen, 1925.

Description. Colony fungiform, simple or complex with stacked subcolonies; stalk formed of kenozooids; head comprising autozooids (and possibly undifferentiated kenozooids), free-walled, larger near centre; gonozooid located on upper side of head between centre and edge, roofed by exterior frontal wall.

Remarks. The type species of Levinsen's (1925) genus was redescribed by Brood (1972: 320). The large zooids near the centre of the head, which are a particular feature of Marssoniella, may be closed by sunken diaphragms. Voigt (1974) described another species of Marssoniella, $M$. cenomana from the mid-Cretaceous of 
Germany, and referred the genus to the Corymboporidae. He also figured the small gonozooid of $M$. reticulata (Voigt 1974: fig. 4).

Distribution. Cretaceous (Cenomanian) - Paleocene (Danian), Europe.

\section{Neofungella Borg, 1933}

Type species. Heteropora claviformis Waters, 1904.

Description. Colony fungiform, simple or complex with stacked subcolonies; stalk formed of free-walled autozooids and kenozooids, broadening gradually towards head; head convex, dome-shaped, comprising autozooids with interspersed smaller kenozooids, both free-walled; gonozooid located on upper side of head near centre, with roof of (?) exterior wall, overgrown.

Remarks. Based on Waters' (1904) species Heteropora claviformis, Neofungella was proposed and comprehensively described by Borg (1933) in his monograph on the Heteroporidae ( = Cerioporidae). Unlike the other fungiform genera considered here, the stalk, which is not well-differentiated from the head, bears autozooidal as well as kenozooidal apertures. The brood chamber is overgrown by later zooids, and the structure of its roof (exterior or interior wall) and its mode of development are uncertain, although Borg (1933) inferred that skeletal resorption was involved. Moyano (1966) redescribed $N$. claviformis and reassigned it to the Corymboporidae because of the morphology of the brood chamber, but Buge and Tillier (1977) disagreed.

A second species of Neofungella, $N$. califormica Banta, 1967, was described as having a brood chamber in which '...the exposed surface is covered with a delicate framework of cancelli closely adherent to the minutely porous oecium...' (Banta 1967: 37). The 'cancelli' are presumably an overgrowth and the minute pores are suggestive of pseudopores in an exterior walled roof rather than the larger pores seen in brood chamber roofs composed of interior wall.

Brood (1981) tentatively referred his Miocene species ( $N$. ovata) to Neofungella but this species is globular rather than fungiform and may belong in a different genus.

Hillmer et al. (1997) have recently described two Cretaceous (SantonianCampanian) fungiform genera (Bueltenopora and Constrictopora) which resemble Neofungella in colony shape, with a globose head and autozooids opening on the stalk as well as the head.

Distribution. Recent, Antarctic, South Africa, California, Arctic (see Buge and Tillier 1977: fig. 7).

\section{Penciletta Gray, 1848}

Type species. Tubulipora penicillata (Fabricius, 1780).

Description. Colony developing numerous fungiform subcolonies, several stalks arising from each base, subcolonies sometimes stacked; erect dendroid branches may also be present; adnate base extensive, ramifying and bearing autozooids; stalk formed of exterior wall; head sometimes concave, comprising non-fasciculate autozooids arranged in alternating rows; autozooids fixed-walled, opening all over 
upper surface of head; gonozooids occupying head centre, extending between autozooids.

Remarks. This little-used genus contains only the type species, the rare $P$. penicillala, originally described by Fabricius (1780), which is usually known as Tubulipora penicillata and placed within the family Tubuliporidae (Hayward and Ryland 1985). Kluge (1975) described $P$. penicillata as having erect branches terminating in discoidal heads, from the margins of which new erect branches grow. The fungiform parts of the colonies were said to arise from the surfaces of both encrusting and erect branches.

Distribution. Recent, arctic-boreal Atlantic.

\section{Supercytis d'Orbigny, 1853}

Type species. Supercytis digitata d'Orbigny, 1853.

Description. Colony fungiform, simple; stalk formed of exterior wall; head comprising radial fascicles of autozooids, fascicles sometimes extending significantly beyond edge of head, bounded by exterior wall; autozooids opening around edge of head; gonozooids located at centre of head, subcircular, with exterior frontal walls.

Remarks. The type species of Supercytis was redescribed by Voigt (1972) using the original material of d'Orbigny (1853) from the Upper Cretaceous (Coniacian) of Fécamp, France.

There has been some confusion between Supercylis and Telopora Canu and Bassler, 1920, not least because of the existence of two superficially similar species sharing the same specific name but generally referred to different genera, viz. $S$. digitata d'Orbigny, 1853 and Fasciculipora digitata $=T$. digitata (Busk, 1875) (see Busk 1886). The two genera have a very similar colony form, with fascicles extending beyond the outer margins of the head and the gonozooid located on the central upper surface of the head. Based on existing descriptions, the principal difference between the genera is that the roof of the gonozooid is complete in Supercytis but penetrated by numerous autozooidal apertures in Telopora (see below).

Supercytis tubigera Busk, 1886 has small, globular brood chambers on the upper surface of the head close to the fascicle bases, whereas the brood chambers are centrally placed in S. digitata. Neverthless Busk's species from Heard Island (Kerguelen Plateau) is provisionally included in Supercytis.

Bassler (1953) placed Supercytis in the Cytididae.

Distribution. Cretaceous (Coniacian, ?Campanian), Europe - Recent, southern Indian Ocean.

Telopora Canu \& Bassler, 1920

Type species. Supercytis watersi Harmer, 1915.

Description. Colony fungiform (Fig. 20), sometimes laterally compressed, simple or compound with stacked subcolonies or multiple subcolonies arising from a ramifying, encrusting base; stalk formed of exterior wall (Fig. 21); head in skeletally mature colonies comprising radial, bifurcating fascicles/branches of autozooids, fascicles extending beyond edge of head, bifurcating, bounded basally and laterally 
by exterior wall continuous with that of the stalk; autozooids on fascicles/branches free- or fixed-walled; centre of head comprising free- or fixed-walled autozooids and kenozooids; gonozooid located on upper surface of head (Fig. 22), with exterior frontal wall penetrated and supported by autozooids, singly or in groups.

Remarks. Telopora is distinguished by the prominent fascicles of autozooids which extend well beyond the margins of the head to form short, bifurcating branches, together with the centrally-located gonozooid whose roof is penetrated (Fig. 22) and supported by numerous autozooidal apertures (sometimes occluded). The systematics of the genus are complicated by changes in appearance between colonies at different developmental stages. Young, infertile and occasionally fertile colonies have no fascicles and instead the entire upper surface of the head is occupied by free-walled zooids (Fig. 22). Skeletally mature colonies have branches bearing fixed-walled autozooids at the edges of the head and a fixed-walled gonozooid occupying the centre of the head, penetrated by autozooidal apertures.

In addition to the type species (Supercytis watersi), first described by Harmer (1915), Canu and Bassler (1920: 807) assigned 'Supercytis digitata Waters, 1884' to their new genus. However, Waters (1884) was not the author of a species called Supercytis digitata but, confusingly, redescribed under the heading 'Supercytis? digitata d'Orb' a Tertiary (Miocene?) fossil species from South Australia which is not the Cretaceous Supercytis digitata of d'Orbigny (1853) but may possibly be Fasciculipora digitata Busk, 1875, a Recent species of Telopora from Cape Capricorn, Queensland (Busk 1875). Waters (1887) later described what he took to be the same species from the Pleistocene of Wanganui in New Zealand. This is likely to be Telopora lobata (Tenison-Woods, 1880) which differs from the type species of the genus in having the gonozooid roof penetrated by several clusters of autozooids rather than numerous single autozooids. The Recent material from Hauraki Gulf, New Zealand, described by Whitten (1979) as Telopora digitata (Busk, 1875), has brood chambers not penetrated by autozooidal apertures. By the generic definition adopted here, therefore, it is a species of Supercytis.

A species described by Canu and Bassler (1920), T. patens from the Eocene Castle Hayne Limestone of North Carolina, was ambiguously assigned by them to Telopora in their original description of this genus. The generic attribution of $T$. patens is not questioned in their plate caption, but the species heading in the text is preceded by a question mark whereas the description that follows states, 'This species is not a Telopora'.

Extensive revision of type and other material of these putative species of Telopora is needed before generic assignments and the number and correct names for the species represented can be ascertained fully. Bassler (1953) placed Telopora in the Family Tretocycloeciidae, but the existence of fixed-walled autozooids suggests that it is more correctly assigned to a tubuliporine family (?Cytididae) rather than this cerioporine family.

Distribution. ?Eocene, Miocene-Recent, Australasia, East Indies and (?) North America.

Trochiliopora Gregory, 1909a

Type species. Trochiliopora humei Gregory, 1909a. 
Description. Colony fungiform, simple; stalk formed of kenozooids; head comprising free-walled autozooids opening in uniserial rows or multiserial fascicles near edge of head, separated by free-walled kenozooids, not projecting significantly; centre of head formed of free-walled kenozooids; gonozooid unknown in type species, free-walled and located in centre of upper surface of head in a possible Miocene congener.

Remarks. The type species, T. humei from the Chalk of England, was originally described by Gregory (1909a), more fully by Gregory (1909b), and revised by Thomas (1939), who added a second Chalk species to the genus, $T$. gasteri, differing from $T$. humei in having a multiserial arrangement of autozooidal apertures. Unfortunately, the brood chamber is unknown in either of these two Cretaceous species. However, in Trochiliopora? insignis (Manzoni, 1878) (see Vávra 1974), another species with autozooidal apertures in multiserial fascicles, it has a roof of apparent interior wall and is located on the upper surface of the head (Schattleitner 1991: pl. 2, fig. 2). A second European Miocene species was recently admitted to the genus by Pouyet (1997) as Trochiliopora beyrichi (Reuss, 1851).

Gregory (1909b) assigned Trochiliopora to his own family the Radioporidae, and Bassler (1953) assigned it to the Lichenoporidae.

Distribution. Cretaceous (Coniacian) - ?Middle Miocene, Europe.

In addition to the cyclostomes described above, fungiform or sub-fungiform colonies occur in some other genera for which neither adequate material nor descriptions were available. These genera include: (1) Hypocytis Ortmann, 1889 (Ortmann 1889: 66), type species $H$. asteriscus Ortmann, 1889 (p. 66, pl. 2, fig. 19), Recent, Japan; and (2) Umbrellina Reuss, 1872 (Reuss 1872: 119), type species $U$. stelzneri Reuss, 1872 (p. 119, pl. 29, fig. 11), Cretaceous, Europe (sec Voigt 1981: fig. $2 \mathrm{~g}-\mathrm{i})$.

This brief review of fungiform cyclostomes points to the existence of about 17 to 20 nominal genera characterized by this growth-form. The family-level affinities of many of these genera are uncertain. Nevertheless, at least 10 families have been proposed for the reception of particular genera: Cerioporidae (=Heteroporidae), Corymboporidae, Cytididae, Fasciculiporidae, Frondiporidae, Fungellidae, Lichenoporidae, Radioporidae, Theonoidae, and Tubuliporidae. Inasmuch as classification reflects phylogeny, the inclusion of fungiform cyclostomes in such a large number of families makes it very likely that the fungiform colony-form has evolved independently in many different cyclostome clades.

\section{Functional Morphology}

Information on the environmental distribution of fungiform bryozoans is limited and contributes little to an understanding of the functional morphology of the grow th-form. Some nodular to fungiform, multilayered cheilostome colonies apparently inhabit tranquil environments, such as caves (Harmelin 1985; Scholz and Hillmer 1995), where planktonic food supplies may be low and competition from other sessile encrusters and pressure from predators reduced. However, other fungiforms lived in open, higher energy environments (e.g. Hillmer et al. 1997) 
where very different conditions of food, competition and predation are expected to prevail.

An alternative approach to understanding the functional significance of fungiform colonies involves a consideration of their geometrical properties (cf. Jackson 1979). The key features of fungiform colonies are the relatively small area of attachment to the substratum, the stalk usually without feeding zooids, and the head with feeding zooids opening on the upper surface and/or around the edge. Colonies are essentially 'semi-erect' in that they grow away from the substratum but only to a limited degree. By raising the apertures and lophophores of the feeding zooids, fungiforms potentially achieve some immunity from colony mortality or partial mortality of zooids caused by spatial competitors sharing the same substratum, or by predators encroaching along the surface of the substratum. Fungiform colonies with stalks covered by kenozooids are predicted to show an active response to spatial competitors because of the potential ability of their kenozooids to continue growing and counter competitors. Such a response may not be possible in genera with 'inert' exterior walls covering the stalk surface.

Elevation of the feeding zooids on the stalk also takes them into regions of higher current flow within the boundary layer. This is expected to be of particular importance in caves and other habitats with low ambient current flows. No observations of feeding in fungiform colonies have yet been published, but the arrangement of the feeding zooids on the head is strongly suggestive of colony-wide feeding currents like those seen in many other bryozoans (see McKinney and Jackson 1989; McKinney 1990). Simple fungiform colonies and individual subcolonies of compound fungiform colonies probably function as distinct feeding units. The centre of the head in fungiforms generally lacks feeding zooids (e.g. Figs $2,4,15$ ) and can be inferred to act as a chimney for venting the excurrent flows of the autozooids. In fungiform colonies with autozooidal apertures arranged in radial fascicles (e.g. Figs $2,3,15$ ), it is likely that the excurrent flows of the autozooids are first directed into the grooves between the fascicles and then channeled centripetally towards the colony centre, as observed by Cook (1977) for some non-fungiform cyclostomes with comparable radial arrangements of autozooids. Efficiency of feeding in fungiform cyclostomes is expected to be increased by such multizooidal, colony-wide feeding currents.

\section{Acknowledgements}

We thank Dr D. P. Gordon (NIWA, Wellington), Prof. E. Voigt (Hamburg Universität) and Prof. S. Mawatari (Hokkaido University) for discussion. AVG gratefully acknowledges the Otto Kinne Fund (Ecology Institute, Oldendorf/Luhe, Germany) and the Lerner-Gray Fund (American Museum of Natural History) for financial support.

\section{References}

Androsova, E. 1. 1962. Bryozoa of the north-eastern part of the Pacific Ocean. Abstract of report. Pp. 1-6. In: Conference on Fauna and Flora Combined Researches. Zoological Institute, 
Academy of Sciences of the USSR, Leningrad. [In Russian]

Banta, W. C. 1967. A new species of Neofungella (Bryozoa, Stenolaemata) from southern California. Bulletin of the Southern California Academy of Sciences 66: 35-38.

Bassler, R. S. 1953. Bryozoa. In: Moore, R. C. (Ed.), Treatise on Invertebrate Paleontology, Part G. Geological Society of America and University of Kansas Press, New York and Lawrence, xiv $+253 \mathrm{pp}$.

Borg, F. 1933. A revision of the recent Heteroporidae (Bryozoa). Zoologiska Bidrag från Uppsala 14: 253-394.

Borg, F. 1944. The stenolaematous Bryozoa. Pp. 1-276. In: Bock, S. (Ed.) Further Zoological Results of the Swedish Antarctic Expedition 1901-1903. Norstedt \& Söner, Stockholm.

Brood, K. 1972. Cyclostomatous Bryozoa from the Upper Cretaceous and Danian in Scandanavia. Stockholm Contributions in Geology 26: 1-464.

Brood, K. 1981. Miocene Bryozoa from Guadal Formation at the southern border of Lago General Carrera, Aysen region of Chile, South America. Revista Geologica de Chile 12: 59-77.

Buge, E. and Tillier, S. 1977. Doliocoitis atlantica n. gen. n. sp., Cériopore (Bryozoa, Cyclostomata) des côtes d'Afrique occidentale. Bulletin du Museum d'Histoire Naturelle (3) 425: 1-24.

Busk, G. 1875. Catalogue of Marine Polyzoa in the Collection of the British Museum. Trustees of the British Museum, London, $41 \mathrm{pp}$.

Busk, G. 1886. Report on the Polyzoa (Part II). Report on the Scientific Results of the Voyage of H.M.S. Challenger, Zoology 17 (50): 1-47.

Canu, F. and Bassler, R. S. 1920. North American Early Tertiary Bryozoa. Bulletin of the United States National Museum 106: 1-879.

Canu, F. and Bassler, R. S. 1922. Studies on the cyclostomatous Bryozoa. Proceedings of the United States National Museum 61 (22): 1-154.

Cook, P. L. 1977. Colony-wide water currents in living Bryozoa. Cahiers de Biologie Marine 18: $31-47$.

Fabricius, O. 1780. Fauna Groenlandica. Rothe, Hafniae and Lipsiae, 452 pp.

Flor, F. D. 1975. Discotruncatulipora corbis n. g. n. sp. (Bryoz. Cycl.) aus der Oberen Kreide. Mitteilungen aus dem Geologisch-Paläontologischen Institut der Universität Hamburg 44: 99-110.

Gordon, D. P. and d'Hondt, J.-L. 1997. Bryozoa: Lepraliomorpha and other Ascophorina, mainly from New Caledonian waters. Mémoires du Muséum National d'Histoire Naturelle 17: 9-124.

Gray, J. E. 1848. List of the Specimens of British Animals in the Collection of the British Museum. Part 1. Centroniae and Radiated Animals. Trustees of the British Museum, London, 173pp.

Gregory, J. W. 1907. The rotaform Bryozoa of the Isle of Wight. Geological Magazine (5) 4: $442-443$.

Gregory, J. W. 1909a. New species of Cretaceous Bryozoa. Geological Magazine (5) 6: 61-66.

Gregory, J. W. 1909b. Catalogue of the Fossil Bryozoa in the Department of Geology, British Museum (Natural History). The Cretaceous Bryozoa. Volume II. Trustees of the British Museum, London, 346pp.

Grischenko, A. V., Gordon, D. P. and Taylor, P. D. In press. A unique new genus of cheilostomate bryozoan with reversed-polarity zooidal budding. Asian Marine Biology 14: 000-000.

Hagenow, F. v. 1851. Die Bryozoen der Maastrichter Kreidebildung. Fischer, Cassel, xv $+111 \mathrm{pp}$. Hara, U. and Taylor, P. D. 1996. Jurassic bryozoans from Baltów, Holy Cross Mountains, Poland. Bulletin of The Natural History Museum, London, (Geology Series) 52: 91-102.

Harmelin, J.-G. 1985. Bryozoan dominated assemblages in Mediterranean cryptic environments. Pp. 135-143. In: Nielsen, C. and Larwood, G. P. (Eds) Bryozoa: Ordovician to Recent. Olsen and Olsen, Fredensborg. 
Harmer, S. F. 1915. The Polyzoa of the Siboga Expedition. Part 1. Entoprocta, Ctenostomata and Cyclostomata. Siboga-Expeditie 28a: 1-180, pls 1-12.

Hayward, P. J. and Ryland, J. S. 1985. Cyclostome bryozoans. Synopses of the British Fauna (New Series) 34: 1-147.

Hillmer, G., Voigt, E. and Scholz. J. 1997. Neue fungiforme Bryozoen-Genera (Cyclostomata) aus dem subhercynen Santonium und ihre Ökologie. Courier Forschungsinstitut Senckenberg 201: 201-223.

Izyumova, E. A. 1977. Data on the ecology of Western Kamchatka Shelf Cheilostomata. Abstracts of Reports. 1st All-Russian Marine Biology Conference. Pp. 59-60. Vladivostok. [In Russian]

Jackson, J. B. C. 1979. Morphological strategies of sessile animals. Pp. 499-555 In: Larwood, G. and Rosen, B. R. (Eds) Biology and Systematics of Colonial animals. Academic Press, London.

Kluge, G. A. 1953. Class Bryozoa. Pp. 169-179 In: Uschakov, P. V. (Ed.) The Fauna of the Sea of Okhotsk and the Conditions of its Existence. Academy of Sciences of the USSR Press, Leningrad. [In Russian]

Kluge, G. A. 1955. [New and lesser known Bryozoa from the Arctic Ocean. II.] Trudy Zoologicheskogo Instituta Akademiya Nauk SSSR 18: 63-99. [In Russian]

Kluge, G. A. 1975. Bryozoa of the Northern Seas of the USSR. Amerind Publishing Co. Ltd., New Delhi, $711 \mathrm{pp}$.

Lamouroux, J. 1821. Exposition Méthodique des Genres de l'Ordre des Polypiers. Agasse, Paris, 115 pp., 84 pls.

Levinsen, G. M. R. 1925 Unders $\emptyset$ gelse over Bryozoerne i den danske Kridtformation. Kongelige Danske Videnskabernes Selskabs Skrifter (8) 7: 283-445, pls 1-8.

McKinney, F. K. 1990. Feeding and associated colonial morphology in marine bryozoans. Reviews in Aquatic Sciences 2: 255-280.

McKinney, F. K. and Jackson, J. B. C. 1989. Bryozoan Evolution. Unwin Hyman, Boston, 238pp.

MacGillivray, P. H. 1886. Descriptions of new, or little known, Polyzoa. Part XI. Proceedings of the Royal Society of Victoria 23: 64-72.

Michelin, H. 1841-8. Iconographie Zoophytologique, Description par Localités et Terrains des Polypiers Fossiles de France et Pays Environnants. Bertrand, Paris, viii $+348 \mathrm{pp}$.

Moyano, I. 1966. Bryozoa colectados por la Expedición Antártica Chilena 1964-1965. II. Familia Corymboporidae Smitt, 1866 (Bryozoa, Cyclostomata). Publicaciones del Instituto Antmg ti co Chileno 11: 1-17.

Orbigny, A. d' 1850. Prodrome de Paléontologie Stratigraphique Universelle des Animaux Mollusques et Rayonnés. 1. Masson, Paris, 394pp.

Orbigny, A. d' 1851-4. Paléontologie Française, Terrains Crétacé, 5, Bryozoaires. Masson, Paris, $1192 \mathrm{pp}$.

Ortmann, A. 1889. Die Japanische Bryozoenfauna. Archiv für Naturgeschichte 56: 1-74.

Osburn, R. C. 1953. Bryozoa of the Pacific Coast of America. Part 3, Cyclostomata, Ctenostomata, Entoprocta, and addenda. Allan Hancock Pacific Expeditions 14 (3): 613-841.

Pergens, E. and Meunier, A. 1887. La faune des Bryozoaires Garumniens de Faxe. Annales de la Société Royale Malacologique de Belgique 27: 187-242.

Pouyet, S. 1997. Les Bryozoaires du Badénien (Miocéne Moyen) d'Olimpow (Pologne). Documents des Laboratoires de Géologie Lyon 145: 1-125.

Reuss, A. E. 1872. Die Bryozoen und Foraminiferen des unteren Planers. Palaeontographica 20 (1): 95-144, pls 24-33.

Ross, J. R. P. 1970. Keys to the Recent cyclostome Ectoprocta of marine waters of northwest Washington State. Northwest Science 44: 154-169. 
Sars, M. 1851. Beretning om en Zoologisk Reise i Sommeren 1849 i Lofoten og Finmarken. Nyt Magazin for Naturvidenskab 6: 121-211.

Savilov, A. N. 1961. Ecological description of Sea of Okhotsk bottom communities. Trudy Instituta Okeanologii 46: 3-34. [In Russian]

Schäfer, P. 1991. Brutkammern der Stenolaemata (Bryozoa): Konstruktionsmorphologie und phylogenetische Bedeutung. Courier Forschungsinstitut Senckenberg 136: 1-263.

Schattleitner, M. 1991. Contribution to the taxonomy of some encrusting cyclostome Bryozoa from the Miocenc of the Paratethys. Bulletin de la Société des Sciences Naturelles de l'Ouest de la France, Mémoire HS1: 391-397.

Scholz, J. and Hillmer, G. 1995. Reef-bryozoans and bryozoan-microreefs: control factor evidence from the Philippines and other regions. Facies 32: 109-144.

Taylor, P. D. 1987. Bryozoans. Pp. 30-49. In: Owen, E. (compiler) and Smith, A. B. (editor) Fossils of the Chalk, Palaeontological Association, London.

Taylor, P. D. and McKinney, F. K. 1996. An Archimedes-like cyclostome bryozoan from the Eocene of North Carolina. Journal of Palcontology 70: 218-229.

Thomas, H. D. 1939. On Trochiliopora humei Gregory and T. gasteri sp. nov. Proceedings of the Geologists' Association 50: 527-529.

Vávra, N. 1974. Cyclostome Bryozoen aus dem Badenian (Mittelmiozän) von Baden bei Wien (Niederösterreich). Neues Jahrbuch für Geologie und Paläontologie Abhandlungen 147: $343-375$.

Vávra, N. 1978. Bobiesipora n. g. - eine neue Gattung der Cyclostomata (Bryozoa) aus dem österreichischen Neogen. Annalen des Naturhistorischen Museums, Wien 81: 229-235.

Vávra, N. 1983. Bryozoen aus dem Unteren Meeressand (Mitteloligozän) von Eckelsheim (Mainzer Becken, Bundesrepublik Deutschland). Mainzer Naturwissenschaftliche Arkiv 21: 67-123.

Voigt, E. 1951. Das Maastrichter-Vorkommen von Ilten bei Hannover und seine Fauna. Mitteilungen aus dem Geologischen Staatsinstitut in Hamburg 20: 15-109.

Voigt, E. 1972. Sur quelques espéces de Bryozoaires cyclostomes Crétacés décrites par A. d'Orbigny. Annales de Paléontologie (Invertébrés) 58: 203-220.

Voigt, E. 1973. Bryozoen aus dem Santon von Gehrden bei Hannover. I. Cyclostomata. Bericht der Naturhistorischen Gesellschaft zu Hannover 117: 111-147.

Voigt, E. 1974. Zwei neue cyclostome Bryozoen der Familie Corymboporidae (SMITT) im Cenoman von Mülheim-Broich (Ruhr). Neues Jahrbuch für Geologie und Paläontologie Abhandlungen 146: 195-220.

Voigt, E. 1977. Infundibulipora huckriedei n. sp. (Bryoz. Cyclostomata) from the Upper Cretaceous of Iran and Western Europe (with remarks on the genus Infundibulipora Brood, 1972). Journal of the Palaeontology Society of India 20 (for 1975): 230-236.

Voigt, E. 1981. Répartition et utilisation stratigraphique des Bryozoaires du Crétacé moyen (Aptien-Coniacien). Cretaceous Research 2: 439-462.

Voigt, E. 1987. Die Bryozoen des Klassischen Dano-Montiens von Mons (Belgien). Mémoires pour Serviràl'Explication des Cartes Gćologiques et Minières de la Belgique 17 (3): 1-161.

Walter, B. 1967. Révision de la faune de Bryozoaires du Bajocien supérieur de Shipton Gorge (Dorset, Grande-Bretagne). Travaux des Laboratoires de Géologie de la Faculté des Sciences de Lyon (n.s.) 14: 13-52.

Walter, B. 1970. Les Bryozoaires Jurassiques en France. Documents des Laboratoires de Géologie de la Faculté des Sciences de Lyon, 35 (for 1969): 1-328.

Walter, B. 1986. Les Bryozoaires Fasciculés Néocomiens. Palaeontographica, Abt. A, 195: 75-99.

Waters, A. W. 1884. Fossil cyclostomatous Bryozoa from Australia. Quarterly Journal of the 
Geological Society of London 40: 674-697.

Waters, A. W. 1887. On Tertiary cyclostomatous Bryozoa from New Zealand. Quarterly Journal of the Geological Society of London 43: 337-350.

Waters, A. W. 1904. Bryozoa. Résultats du Voyage du S.Y. Belgica en 1897-1898-1899, Rapports Scientifiques, Zoologie. Buschmann, Anvers, 114pp.

Whitten, R. F. 1979. Systematics and Ecology of Northern Hauraki Gulf Bryozoa. Unpublished Ph.D. thesis, University of Auckland.

\section{APPENDIX}

Key to the identification of fungiform cyclostome genera.

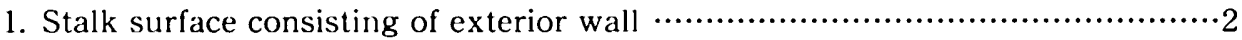

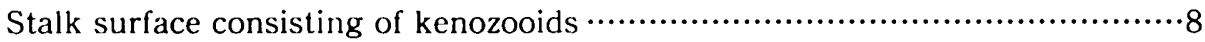

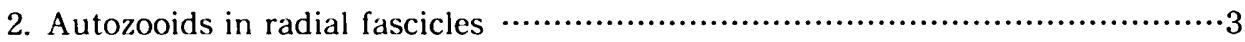

Autozooids not in fascicles

3. Brood chamber ovoidal, visible on underside of head …..... Discotruncalulipora Brood chamber not visible on underside of head ….................................4

4. Brood chamber on edge of head between fascicles........................ Apsendesia

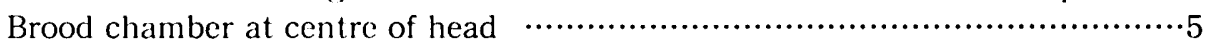

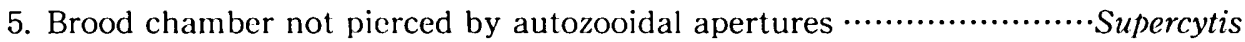
Brood chamber profuscly pierced by autozooidal apertures …............. Telopora

6. Autozooids with exterior walls (fixed-walled) …...........................Penciletta

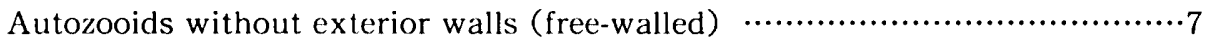

7. Head with differentiated kenozooids …................................ Discofascigera Head without differentiated kenozooids …............................Fasciculiporina

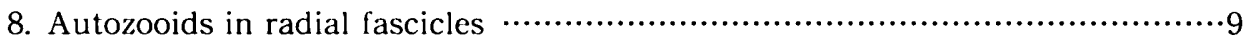

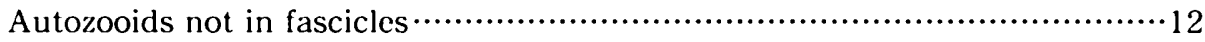

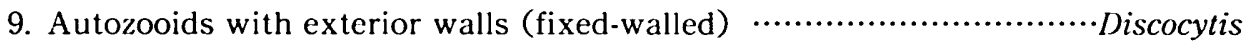

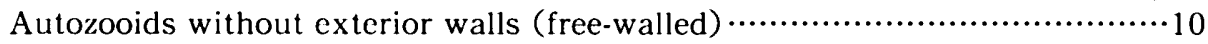

10. Fascicles of low profilc, not projecting from edge of head …...........Rodinopora

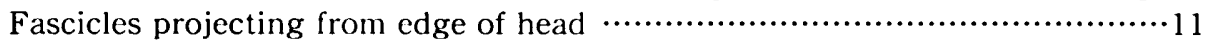

11. Brood chamber roof of exterior wall (fixed-walled) …............... Infundibulipora Brood chamber roof of interior wall (free-walled) $\cdots . . . . . . . . . . . .$. Trochiliopora Brood chamber unknown …..................................................... Bicavea

12. Head with differentiated kenozooids ….............................................. 13

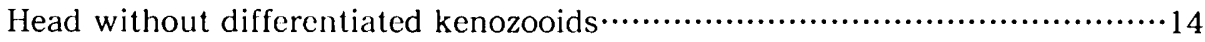

13. Autozooidal apertures raised above surrounding kenozooids …......Flosculipora

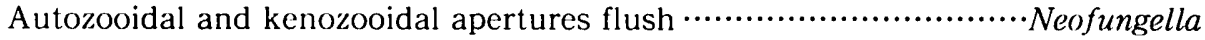

14. Brood chamber located at edge of head, very narrow............ Amphimarssoniella

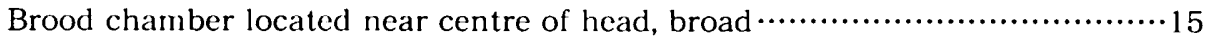

15. Brood chamber roof of exterior wall (fixed-walled) $\ldots . . . . . . . . . . . . . .$. Marssoniella Brood chamber roof of interior wall (free-walled) ….......................... Fungella

* based on Trochiliopora? insignis (Manzoni, 1878) as redescribed by Schattleitner (1991: 396, pl. 2, figs 2-3) 
